Published in International journal of hospitality management, 2016, vol. 59, pp. 31-41, which should be cited to refer to this work.

\title{
AM I DOING THE RIGHT THING?
}

\section{UNPACKING WORKPLACE RITUALS AS MECHANISMS FOR STRONG ORGANIZATIONAL CULTURE}

\author{
Niclas Erhardt * \\ Maine Business School \\ University of Maine \\ 5723 D.P. Corbett Business Building \\ Orono, ME 04469-5723, USA \\ +1207-581-3671 \\ niclas.erhardt@maine.edu \\ Carlos Martin-Rios*
}

Ecole hôtelière de Lausanne // HES-SO University of Applied Sciences Western Switzerland 1000 Lausanne 25, Switzerland carlos.martin.rios@ehl.ch

Charles Heckscher

School of Management and Labor Relations

Rutgers University

50 Labor Center Way

New Brunswick, NJ 08903

cch@heckscher.us

Erhardt, N., Martin-Rios, C. \& Heckscher, C. (2016). Am I doing the right thing? Rituals as institutional learning mechanisms for organizational culture in restaurants. International Journal of Hospitality Management, 59: 31-41

Acknowledgements: We express our appreciation to owners and employees at the restaurants for providing access and insight into the challenges of workplace rituals. Our thanks to Camilo Garcia, Director of the Laboratory of Social Interaction, Universidad Veracruzana and Marc Stierand, Ecole hôtelière de Lausanne, for their helpful comments and suggestions. We also thank Joshua Deakin for his help with this project. This work was partially funded by the University of Applied Science of Western Switzerland (HES-SO) research project $N^{\circ} 45284$. 


\title{
AM I DOING THE RIGHT THING? \\ UNPACKING WORKPLACE RITUALS AS MECHANISMS FOR STRONG ORGANIZATIONAL CULTURE
}

\begin{abstract}
Workplace rituals are powerful learning mechanisms for core values that underpin organizational culture in restaurants. Yet, more research is needed to identify different types and how these rituals operate to reinforce core values in different organizational cultures. Drawing on ritual theory, organizational culture and hospitality research, we use 52 semi-structured interviews and 20 observations to study four restaurants representing clan, ad hoc, market, and hierarchy cultures. We identify and unpack eight employee-focused emotional, behavioral, and cognitive workplace rituals linked with owners' core values such as comradery, creativity, competition and efficiency. Finally, we discuss practical implications of workplace rituals as they relate to business identity, selection, retention and day-to-day management of employees to further strengthen said culture.
\end{abstract}

Keywords: Restaurants; Rituals, Organizational Culture, Core Values; Learning, Hospitality Management 


\section{Introduction}

When asked, professionals often struggle with defining organizational culture and revert to the answer as 'how things are done around here' and 'what we do when nobody is looking'. Experts on the subject typically define organizational culture as a complex system of shared values that guides actions of organizational members (O'Reilly et al., 1991). Values such as camaraderie, creativity, performance and efficiency operate as underpinnings of the organization's culture that creates an identity, and sets it apart from competitors (Coffey, 2010; Denison, 1984; Sorensen, 2002). While organizational culture has received more attention in the broader hospitality management domain, generally framed around the importance of strong values of quality customer service (Davidson, 2003; Dawson et al., 2011; Clark and Wood, 1998), less attention has been paid to organizational culture and the importance of workplace rituals in restaurantsdefined as symbolic social actions of core values (Miller, 1985). This is surprising as the culture, typically established by the owner (Schein, 2010), is likely to enhance a competitive edge (Barney, 1986) with supporting workplace rituals that guides employee actions to deliver superior customer experience, generate loyal patrons, and market share.

For a value-driven restaurant to succeed, commitment and consistency to core values are important, however this is problematic given the nature of the industry marked by high stress, long hours, low skill, low employee commitment, low pay, high turnover, and high first-year failure rates (Madera et al., 2013; Parsa et al., 2005; Sparrowe, 1994). Hence, institutional learning mechanisms through which core values can be shared and reinforced seem critical to deploy (Durand et al., 2007; Rao et al., 2003). Our premise is that workplace rituals can serve as institutional learning mechanisms in different cultures with different core values stemming from the restaurant owner's values (Cameron and Quinn, 1999). Workplace rituals can reinforce a moral consensus of what is acceptable conduct through social action - by participating in rituals, 
individuals learn right from wrong and reinforce the understanding that ' $I$ am doing the right thing!' As such, workplace rituals in restaurants have the potential to shape and strengthen a particular culture (Woods, 1991; Stierand et al., 2014).

We draw on ritual theory (Smith \& Stewart, 2011), organizational culture (Cameron and Quinn, 1999), hospitality research (e.g., Wood, 2010), and make several key contributions in this paper. First, we respond to the call for more research on workplace rituals in general (Islam and Zyphur, 2009) to examine valid rituals and refine existing types of rituals. Specifically, we offer quasi-grounded theory of eight different rituals that we unpack within the context of four restaurants. Second, our data and analysis illustrate how different workplace rituals, geared towards employees, operate as institutional learning mechanisms to foster different organizational cultures linked with the owner's core values. Finally, we offer practical insights as to how rituals can help strengthen culture in the context of restaurants, which is essential in creating a business identity and in differentiating oneself from the competition.

The following sections leading up to our method section are organized by first discussing core values and the role of the owner in establishing these values. Next, we introduce Cameron and Quinn's (1999) cultural framework, which we used to make sense of our field data. We then ground our framing further by linking ritual types with core values, and the importance of symbolism to differentiate rituals from non-rituals in the workplace.

\section{Conceptual Background}

\subsection{Owners and Core Values}

Core values serve as an underlying foundation of a strong organizational culture (Ogbonna, 1993). Core values such as risk-taking and attention to detail, constitute collective knowledge (i.e., understanding) within an organization that is rooted in principles, code-of-conduct, beliefs or philosophy of how the organization operates. These core values are generally established by 
the owner (or the founder) of the restaurant. The owner's values reflect the personal vision, goals, beliefs and assumptions underlying his/her core values (Schein, 2004). These values are initially infused in the organization through careful selections based on similarities of thought, and imposed through hands-on management styles by the owner. Research on top restaurants have examined and found strong links between the organizational culture and the chef's (i.e., owner) vision and underlying values (Stierand et al., 2014).

The owner's ability to instill core values, resulting in stronger culture, is possible to the extent there is congruency between practicing values - what actually happens in organizations (i.e., action) and espoused core values (i.e., understanding) (Argyris and Schon 1996). The stronger ties between employee action and their shared values the greater chance that culture will contribute to higher levels of performance (Saffold, 1988; Smart and John, 1996). This "strong culture" hypothesis has been argued to be perhaps the most important thing an owner can do to create and manage a successful business (Schein, 1992), which can translate into various positive organizational outcomes (Deal and Kennedy, 1982; Sorensen, 2002). However, limited research has focused on how restaurants can foster strong cultures with a few exceptions. For example, Opazo's (2012) study of El Bulli restaurant highlights the relevance of the owner's discourse as a driver of a strong innovative culture in contemporary haute cuisine. Rao et al. (2003) illustrate the relationship between embracing the nouvelle cuisine movement and the development of strong core values and identity in French restaurants. Finally, Wood (2010) points toward certain management methods and practices related to the development of strong culture.

While owners play an essential role in developing and maintaining core values, values may also operate at an industry level, referred to as macro cultures (Abrahamson and Fombrun, 1994). For example, employees at hospitals presumably share core values of health and treatment and in banks core values would involve money and financial growth. Macro culture has also been noted 
in the hospitality and restaurant industries in certain market segments where employees' career path generally follows a series of stints within the same industry (Mulvaney, et al., 2007; Woods, 1989). While macro cultures could facilitate strong culture within the business, the owner's core values and employees' core values may not necessarily square. For example, scholars have noted patterns of strong values of a "party culture" where professional and personal ties tend to blur after hours (O'Neill, 2012), which could trigger unwanted behaviors during work. Moreover, these employee-driven values (i.e., party) can exert influence on the owner, create friction and ultimately undermine service delivery and culture as a whole. Macro cultures may further complicate the owner's attempt to foster strong culture. However, little research has examined how restaurants instill and reinforce core values in order to incorporate staff, deliver a menu and customer service on a consistent basis, and foster strong culture that can create and maintain an identity that is distinct from its competition.

\subsection{Four Types of Organizational Cultures}

Our premise in this paper is that different cultures exhibit different rituals for acquiring knowledge that translate into symbolic actions of core values. While organizational culture is complex and at times difficult to identify, we draw on Cameron and Quinn's (1999) taxonomy of organizational culture to ground our conceptual starting point and help guide our fieldwork. They identified four different cultures (i.e., clan, ad hoc, market, hierarchy) based on an internal/external focus and integration/differentiation, and flexibility/freedom to act, and stability and control that manifest themselves based on different sets of core values. Their framework is widely used in hospitality research (e.g. Koutroumanis et al., 2012) (for alternative value-based frameworks see Adler, Kwom and Heckscher, 2008 and Cumberland and Herd, 2011). To summarize their framework, a clan culture is used, which is a family-based value system centered on friendship, loyalty, mentorship, equality and social support with little concern for external 
competition or hierarchy. An adhocracy culture values creativity, innovation, and employee empowerment through informal routines, with the intention of competing with the external market. Furthermore, a market culture rests on values of market competition and customer needs. Finally, a hierarchy culture, whose value system operates on high division of labor, formal protocols and chain of command, is generally internally focused with little concern for market competition.

There is inconsistent evidence as to which culture in restaurants is more effective in terms of impacting bottom line results (e.g., Cumberland and Herd, 2011; Kyriakidou and Gore 2005). Kyriakidou and Gore (2005), in their benchmarking study, suggested that characteristics of ad hoc cultures (framed as empowerment, cooperative setting of missions and strategies, and development of teamwork) show links with best-performing small- to medium-sized operations. Others suggest that a market culture, which is heavily result-focused, based on efficiency and scale, can drive sales (Øgaard et al., 2005). Moreover, although the restaurant industry is generally painted with a broad brush as a customer service oriented culture (following a macro culture argument) (Davidson, 2003), some evidence suggests that social interaction and belonging among employees (i.e., an inwardly focused culture) might be more valued, especially in independently owned restaurants (O'Neil, 2012).

\subsection{Linking Workplace Rituals and Values}

Stemming from anthropological roots, rituals have been used by sociologists for decades to study and explain social order (Bell, 1997). Durkheim (1961), triggering the functionalist school of thought (with followers such as Talcott Parson, Robert Merton), viewed rituals as a lens to understand how social order is regulated, stabilized and perpetuated. Rituals can operate to govern the inner workings of a social unit (Turner, 1967), which extends to the workplace as well (i.e., an organization). However, rituals do more than just describe the process of maintaining a 
culture. Clifford Geertz and others argued that rituals actively shape social order and impose meaning on disordered experience (Bell, 1997). That is, "ritual practices seek to formulate a sense of the interrelated nature of things and to reinforce values that assume coherent interrelations, and they do so by virtue of their symbols, activities, organization, timing, and relationships to other activities.” (Bell, 1997, p. 136). Rituals at work (i.e., workplace ritual) as an institutional learning mechanism is resilient, inherently serves as an institutional memory of what the organizations value and exists despite turnover among organizational members (Scott, 1995). They tend to remain despite individual turnover, even after the founder is long gone, and promote specific employee behaviors that have worked in the past into routines coupled with symbolic meaning (Crossan et al., 1999). In order for organizational members to fit with organizational culture (i.e., by doing the right thing), there is great pressure to learn and conform to these rituals, stemming from the owner's idea of modus operandi. In a sense, rituals serve to reinforce memory and strengthen the association between action and values (Sosi and Alcorta, 2003).

In a practical sense, any routine or practice that is rooted in core values, would fit under the notion of workplace rituals - workplace rituals are core values in action. Action has symbolic importance in a ritual - the sense that rituals have meaning beyond their mundane and taken-forgranted practice (Radcliffe-Brown, 1952; Trice and Beyer, 1984). Depending on the nature of the ritual, it conveys, through symbolic action, different core values (e.g., personalized service). Unless there is symbolic meaning that transcends the process of going through the motions and generates unity around a common value, it falls outside our definition of workplace rituals. As Miller conveys, "ritualization of work is possible because these activities are inherently meaningless, although they are given meaning with the interpretive context of concrete situations" (1985, p. 5). 
There is an established body of research that has operationalized and used rituals to study cultural forms in organization research (Van Gennep, 2011). For example, Trice and Beyer (1984:655) noted that rituals "involve (1) relatively elaborate and planned sets of activities, (2) carried out through social interactions, (3) usually for the benefit of an audience, (4) with multiple social consequences... [and] involves deliberately planned, carefully managed, and often rehearsed sets of behaviors". Moreover, Smith and Stewart (2011: 114) distinguished between "full rituals", and "ritual-like" activities. They suggested that rituals operate on a spectrum from full to ritual-like activities, where full rituals include: (1) invariability; (2)

formality; (3) symbology; and (4) performance expectations. Even though full rituals are a powerful analytic tool, they are generally infrequent, whereas ritual-like activities are more frequent and a more useful operationalization. Our framing of rituals follows Smith and Stewart's (2011) notion of "ritual-like" with one or multiple traits to understand variations of organizational cultures and how they operate and are transmitted.

\subsection{Rituals in Restaurants}

Emotional, Cognitive and Behavioral Rituals. Most research on rituals has framed rituals as an action-oriented activity involving key behaviors (Islam and Zyphur, 2009). Smith and Stewart (2011) noted that behavioral rituals involve actions performed by employees as part of their daily routines: action oriented rituals that are less mindful, routinized, and automatic. For example, the action of "taking stock of inventory" can simply be a routine task. However, it can also be part of a value system if it is rooted in a belief adhering to order, precision and numbers, in which case it can be viewed as a workplace ritual that occurs through repeated behaviors as a collective activity among employees.

However, symbolism can transcend mere physical behaviors. Smith and Stewart (2011) suggested that rituals can also include values linked with emotion and cognition. Emotional 
rituals involve affective dimensions linked with relationships that symbolize a sense of cohesion and connection among organizational members. For example, reviewing and celebrating the last day's shift performance and rewarding the team as a whole can evoke emotions linked with comradery. Cognitive rituals can include values of creativity, innovation, mental information processing, and decision-making. Practically, evidence of cognitive rituals can include creative problem-solving in teams and diverse thinking symbolized through collective brainstorming meetings and ceremonial awards for innovation.

Rituals as emotional, cognitive and behavioral practices can serve both customers and employees for different reasons. For example, the ritual of singing the national anthem before a sporting event can evoke an emotional response and reinforce belonging among fans (i.e., customers). Customer-based rituals specifically linked with restaurant contexts may include singing happy birthday to a patron while presenting a cake and a lit candle; the maître d' greet and escort patrons to a set dining table; personalizing the check with a thank-you message from the waiter, or dining at the chef's table (Gardner and Wood, 1991). These examples of restaurant rituals are geared towards the customer to develop a relationship and enhance customer experience. Interestingly, scholars have noted the risk of deploying customer-focused rituals as a marketing ploy as they might come across as too formulaic, insincere, potentially creating a reverse effect by turning customers away (Otnes and Lowrey, 2004).

In contrast, this paper focuses on employee-related rituals, which may offer greater depth and understanding as to how a particular culture is shared and reinforced. Examples of employeefocused rituals could include a chant among Walmart employees, performed in the morning before each shift (Kluver et al., 2014) or Ben and Jerry's and its "Joy Squad" where each month a different group of employees dresses up in costumes and walks the offices cheering up their colleagues (Neal, 2013). In the Walmart and Ben and Jerry's examples, the workplace rituals are 
geared towards employees and fostering cohesion. Moreover, Woods (1989) adopting a casestudy approach, offered a useful analysis of five restaurants and examined how employee-focused rituals that were outcome-based can demonstrate appreciation for employees (e.g., giving out "wow" pins for employees that impress customers).

We build on this employee-focus of rituals, and take a deeper look at emotional, cognitive and behavioral workplace rituals as an important institutional learning mechanism. Our research questions are grounded in both Cameron and Quinn's (1999) cultural type, and Smith and Stewart's (2011) ritual type frameworks that serve to help make sense of our fieldwork. Our central research questions formally state:

$R Q$ 1: What types of workplace rituals operate as learning mechanisms to foster strong organizational cultures in restaurants?

$R Q$ 2: How do rituals differ in different restaurants with different organizational cultures?

\section{Method}

We adopted a descriptive, qualitative and case-based approach, anchored in a constructivist paradigm (Hamilton, 1994), which relies on an interaction between the researcher and the participant, in order to understand the relationship between rituals and culture in four local restaurants. The bulk of the data was captured over a nine-month period, generating a total of 52 semi-structured interviews (over 70 hours of recorded data) along with 20 supplemental observations (see Table 1). We interviewed managers, wait staff and cooks in each restaurant to triangulate our data (Mathison, 1988) and many of the participants were interviewed twice. These restaurants operated in the Northeast of the USA in a small college town. Each restaurant differed with respect to their cuisine offered, including pizza, Mexican, hotdogs, and American fusion. We elaborate more on each restaurant below in the findings section. 
Table 1. Demographics of Participants and Observations

\begin{tabular}{|c|c|c|c|c|c|c|}
\hline Age & Restaurant & $\begin{array}{c}\text { Word Count } \\
\text { of Transcript }\end{array}$ & Position & Position Type & Time Employed & Observations \\
\hline $\begin{array}{l}30 \mathrm{~s} \\
20 \mathrm{~s} \\
30 \mathrm{~s} \\
20 \mathrm{~s}\end{array}$ & $\begin{array}{c}\text { Wiener Dog } \\
\text { Wiener Dog } \\
\text { Wiener Dog } \\
\text { Wiener Dog }\end{array}$ & $\begin{array}{l}2724 \\
2654 \\
3165 \\
3500\end{array}$ & $\begin{array}{l}\text { Manager } \\
\text { Cook } \\
\text { Cook } \\
\text { Host }\end{array}$ & $\begin{array}{l}\text { Full } \\
\text { Part } \\
\text { Full } \\
\text { Part }\end{array}$ & $\begin{array}{c}\text { Since Inception } \\
6 \text { Months } \\
1.5 \text { Years } \\
7 \text { Months }\end{array}$ & 4 \\
\hline $\begin{array}{l}60 \mathrm{~s} \\
50 \mathrm{~s} \\
40 \mathrm{~s} \\
20 \mathrm{~s}\end{array}$ & $\begin{array}{l}\text { Classic Pizza } \\
\text { Classic Pizza } \\
\text { Classic Pizza } \\
\text { Classic Pizza } \\
\end{array}$ & $\begin{array}{l}2861 \\
4112 \\
2858 \\
1823 \\
\end{array}$ & $\begin{array}{l}\text { Manager } \\
\text { Waiter } \\
\text { Waiter } \\
\text { Waiter } \\
\end{array}$ & $\begin{array}{l}\text { Full } \\
\text { Full } \\
\text { Part } \\
\text { Part }\end{array}$ & $\begin{array}{c}\text { Over } 30 \text { Years } \\
2 \text { Years } \\
5 \text { Years } \\
6 \text { Months } \\
\end{array}$ & 5 \\
\hline $\begin{array}{l}30 \mathrm{~s} \\
20 \mathrm{~s} \\
20 \mathrm{~s} \\
20 \mathrm{~s}\end{array}$ & $\begin{array}{l}\text { Taco City } \\
\text { Taco City } \\
\text { Taco City } \\
\text { Taco City }\end{array}$ & $\begin{array}{l}3042 \\
3751 \\
1987 \\
3285 \\
\end{array}$ & $\begin{array}{l}\text { Manager } \\
\text { Host } \\
\text { Waiter } \\
\text { Waiter }\end{array}$ & $\begin{array}{l}\text { Full } \\
\text { Part } \\
\text { Part } \\
\text { Part }\end{array}$ & $\begin{array}{l}3 \text { Years } \\
\text { 7/8 Months } \\
\text { 7/8 Months } \\
\text { 7/8 Months }\end{array}$ & 5 \\
\hline $\begin{array}{l}30 \mathrm{~s} \\
30 \mathrm{~s} \\
30 \mathrm{~s} \\
30 \mathrm{~s}\end{array}$ & $\begin{array}{l}\text { Eclectic Table } \\
\text { Eclectic Table } \\
\text { Eclectic Table } \\
\text { Eclectic Table }\end{array}$ & $\begin{array}{l}2929 \\
2486 \\
2451 \\
2417\end{array}$ & $\begin{array}{c}\text { Manager } \\
\text { Waiter/Bartender } \\
\text { Waiter/Bartender } \\
\text { Cook }\end{array}$ & $\begin{array}{l}\text { Full } \\
\text { Full } \\
\text { Full } \\
\text { Full }\end{array}$ & $\begin{array}{c}\text { Since Inception } \\
2 \text { Years } \\
3 \text { Years } \\
\text { Since Inception }\end{array}$ & 6 \\
\hline
\end{tabular}


In our initial sampling strategy, we approached ten local restaurants (both franchised and independently owned), which was roughly 10 percent of the total local restaurant population. We used a set of criteria in order to assess an initial fit with our study and research questions by first interviewing a manager from each restaurant. The criteria were: 1) the restaurant must have been in business over two years with an established culture, 2) it must have more than ten employees to better assess workplace dynamics, and 3) the restaurant must have or have had a founder that established a set of core values. In contrast to quantitative research that commonly adopts random sampling based on statistical deliberations (Miles and Huberman, 1994), these cases were included based on community reputation and familiarity as customers (both authors had dined in each of these restaurants on multiple occasions prior to the study) suitable for exploring organizational culture using Cameron and Quinn's (1999) four-pronged cultural framework. The restaurant industry is notorious for its high failure rate among new restaurants. While the legendary 90 percent first year restaurant failure rate has been debunked, Parsa et al. (2005) provides convincing numbers reporting a 50-60 percent first year failure rate. We did not collect performance data, but it was important that we included restaurants that had been operating for several years with an established culture, which would lend support for our theoretical framing and findings and the fact that rituals identified operated as learning mechanisms in existing and surviving restaurants. Of the ten restaurants approached, six accepted our request to participate. However, as we began collecting data, we later reduced it to four as collecting data became increasingly difficult due to scheduling conflicts. The final two we eliminated were culturally redundant for our $2 \times 2$ framework. Our final four restaurants indicated an initial match with clan, ad hoc, market and hierarchy cultures, which would serve as cases for unpacking the use of workplace rituals. Participants were interviewed at the restaurant or nearby a coffee shop or public space. Participation was strictly voluntary and each informant received a $\$ 10$ gift card as a 
token of appreciation for their time. The interview format followed a semi-structured approach, ranging from 40 to 75 minutes. Each interview was recorded on a smartphone and transcribed shortly thereafter. Questions to assess type of culture were based on a modified version of Cameron and Quinn's (1999) validated cultural assessment instrument (OCAI) and included: to what extent is the organization a personal place (i.e. like an extended family) (Clan); to what extent is the staff part of changing the menu (Ad Hoc); to what extent are formal routines part of work (Hierarchy); and to what extent are people here competitive and achievement oriented (Market).

Rituals and their underlying values can be challenging to detect by the participants themselves and careful examination of statements is necessary in qualitative research. Hammersley (2010: 564) argued that qualitative research "is a slowing down and reflexive re-routing of a process that operates much more rapidly in ordinary social interaction, where we 'hear' what people say: and 'hearing' means understanding what they mean, this necessarily depending upon some grasp of why they are saying and doing what they are, what sort of response may be required, and so on." In slowing down and engaging in a reflexive analytic process, Schein (2010: 343), in his discussion on how to identify values, asks participants: “Why are you doing what you are doing?" For example, if they have said that the place is very informal and that there are few status symbols, I ask why. This usually elicits value statements such as "We value problem solving more than formal authority" or "We think that a lot of communication is a good thing" or even "We don't believe that bosses should have more rights than subordinates." We adopted this "Why?" interview technique, a form of hermeneutical approach (Schwandt, 2000) in our fieldwork to understand core values and unpack rituals as learning mechanisms. We used openended questions, which was especially useful to identify and unpack rituals. Sample questions included: describe your daily work patterns and explain why they are important, what type (if at 
all) of social routines exist in your workplace and why do they exist, and whether you have staff meetings (and, if so, describe them) and why are they are used.

Coding of Data. Next, we linked core values to rituals. Using Smith and Steward's (2011) framing of emotional, cognitive and behavioral rituals as deductive guiding analytical framing for our coding, we explored our data to identify traces of workplace practices and routines that would suggest some level of repetition (invariability), indication about a shared recognized time and space for it (formality), that there was some type of symbolic meaning attached to the practice (symboligy), and that we could trace some individual perception of conformity to participate (performance expectation). If we were unable to identify any symbolic meaning in a workplace practice linked with core values, we discarded it as a non-ritual in the coding process. To further identify, unpack and to understand how rituals operated, we applied Miles and Huberman's (1994) three stage coding process to our transcribed data. Open coding was used as an initial process of identifying rituals in our data. Both individual statements and notes from observations were transcribed and coded. The open coding generated an initial list of 75 codes linked with workplace rituals. Axial coding involved sorting and refining codes into broader categories that emerged from the data that could be viewed as possible rituals. Codes were sorted based on their similarities and potential relationships, creating a set of rituals. Confusing or inconsistent categories were parsed out in separate groups, and reanalyzed to ensure there was no common meaning among them. Selective coding involved integrating and refining initial rituals into a final set of rituals that would serve as a basis for our framework. Table 2 outlines our coding process with sample coding of open, categories (axial) and final eight rituals (selective coding) that serve as a basis for our analysis. The authors, along with a trained graduate research assistant, merged the initial 75 codes into eight types of rituals. We assessed inter-rater reliability for the eight 
rituals on 20 percent of the data. A Cohen's Kappa of .82 demonstrated an initial acceptable level of reliability. The coders met and resolved discrepancies to finalize the coding. 
Table 2. Sample of Open, Axial and Selective Coding

\begin{tabular}{|c|c|c|c|c|}
\hline Open Raw Codes & Axial Categories & Selective Coding & Rituals & $\begin{array}{l}\text { Type of } \\
\text { Culture }\end{array}$ \\
\hline $\begin{array}{l}\text { - No hierarchy } \\
\text { - Retirement parties } \\
\text { - Interaction } \\
\text { - Personal problems are everyone's issues } \\
\text { - Movie night } \\
\text { - Working with friends }\end{array}$ & $\begin{array}{l}\text { - Sharing } \\
\text { - Celebrating family member } \\
\text { - Social connections } \\
\text { - Hired for life }\end{array}$ & $\begin{array}{l}\text { - Personal sharing } \\
\text { - Relationship building }\end{array}$ & Emotional rituals & Clan \\
\hline $\begin{array}{l}\text { - Finding solutions for customer needs } \\
\text { - Teamwork work structure } \\
\text { - Education to think on the spot (wine tasting) } \\
\text { - Staff involvement for menu creation }\end{array}$ & $\begin{array}{l}\text { - Collective menu expansion } \\
\text { - Collaborative learning } \\
\text { - Customer engagement }\end{array}$ & $\begin{array}{l}\text { - Collaborating } \\
\text { - Problem-solving }\end{array}$ & Cognitive rituals & Ad Hoc \\
\hline $\begin{array}{l}\text { - Ranking displayed on a weekly basis } \\
\text { - Training through tests and videos } \\
\text { - Formal employee manual } \\
\text { - Sales objective } \\
\text { - Memorization of menu in } 6 \text { days }\end{array}$ & $\begin{array}{l}\text { - Competition (with other } \\
\text { restaurants) } \\
\text { - By the book } \\
\text { - Selling }\end{array}$ & $\begin{array}{l}\text { - Number checking } \\
\text { - Selling }\end{array}$ & $\begin{array}{l}\text { Behavioral } \\
\text { performance rituals }\end{array}$ & Market \\
\hline $\begin{array}{l}\text { - Note-taking } \\
\text { - Product consistency (despite customer preference) } \\
\text { - List making (Obsession of list and rule conformity) } \\
\text { - Passing of list (sequential work) }\end{array}$ & $\begin{array}{l}\text { - Repetition } \\
\text { - Rule conformity } \\
\text { - Memorization }\end{array}$ & $\begin{array}{l}\text { - Documenting } \\
\text { - Repeating }\end{array}$ & $\begin{array}{l}\text { Behavioral conformity } \\
\text { rituals }\end{array}$ & Hierarchy \\
\hline
\end{tabular}




\section{Findings}

We explored what and how rituals operated as learning mechanisms in four restaurants (using fictitious names and high level descriptions of each restaurant to protect their identity). We departed from Smith and Steward's (2011) framing of emotional, cognitive and behavioral rituals and used it as an initial deductive guiding approach to identify types of rituals. Table 3 distinguishes culture and characteristics, values, ritual characteristics and Figure 1 outlines our eight different rituals placed in Cameron and Quinn's (1999) cultural framework which serve as a guiding reference point in our analysis below.

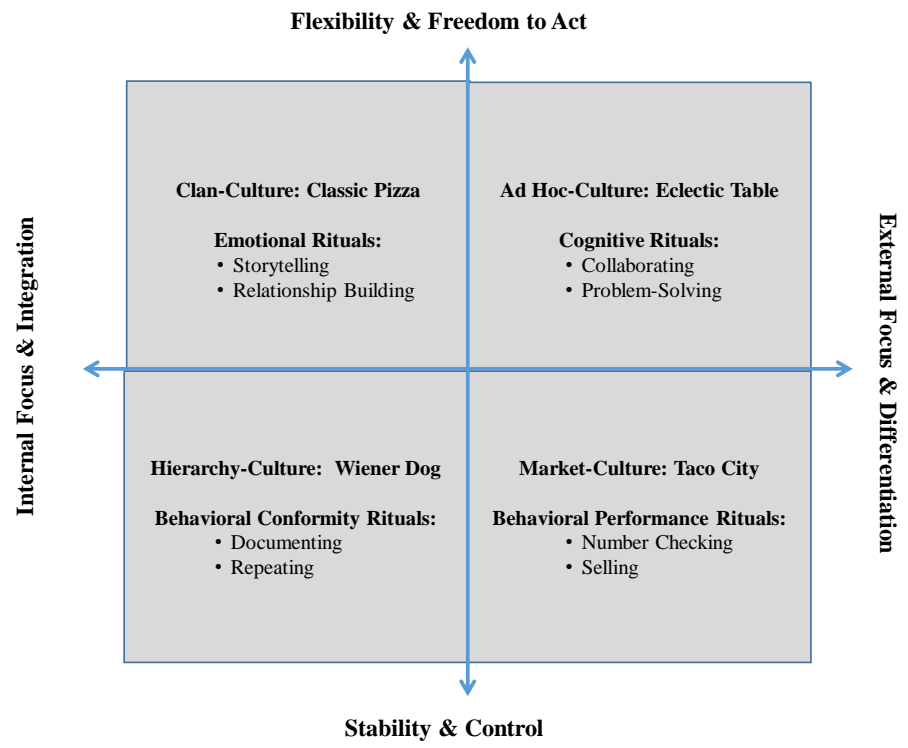

Figure 1. Adapted from Cameron and Quinn (1999) 
Table 3. Linking Culture, Values, Rituals across Cases

\begin{tabular}{|c|c|c|c|c|c|}
\hline Organization & Culture & Characteristics & $\begin{array}{c}\text { Values } \\
\text { (Espoused) }\end{array}$ & Ritual Characteristics & Rituals \\
\hline Classic Pizza & Clan & $\begin{array}{l}\text { - Flexibility and Freedom } \\
\text { - Internal Focus and } \\
\text { Integration }\end{array}$ & $\begin{array}{l}\text { - Family } \\
\text { - Well-being } \\
\text { - Personal Ties } \\
\text { - Cohesion }\end{array}$ & $\begin{array}{l}\text { Emotional } \\
\text { - Teamness } \\
\text { - Comradery } \\
\text { - Caring }\end{array}$ & $\begin{array}{l}\text { - Storytelling } \\
\text { - Relationship } \\
\text { Building }\end{array}$ \\
\hline $\begin{array}{l}\text { Eclectic } \\
\text { Table }\end{array}$ & Ad Hoc & $\begin{array}{l}\text { - Flexibility and Freedom } \\
\text { - External Focus and } \\
\text { Differentiation }\end{array}$ & $\begin{array}{l}\text { - Change } \\
\text { - Creativity } \\
\text { - Learning } \\
\text { - Teamwork }\end{array}$ & $\begin{array}{l}\text { Cognitive } \\
\text { - Mindful } \\
\text { - Decision-making } \\
\text { - Knowledge }\end{array}$ & $\begin{array}{l}\text { - Collaborating } \\
\text { - Problem-Solving }\end{array}$ \\
\hline $\begin{array}{l}\text { Taco } \\
\text { City }\end{array}$ & Market & $\begin{array}{l}\text { - Stability and Control } \\
\text { - External Focus and } \\
\text { Differentiation }\end{array}$ & $\begin{array}{l}\text { - Performance } \\
\text { - Competition } \\
\text { - Efficiency } \\
\text { - Consistency }\end{array}$ & $\begin{array}{l}\text { Behavioral Performing } \\
\text { - Less mindful } \\
\text { - Routinized } \\
\text { - Automatic }\end{array}$ & $\begin{array}{l}\text { - Number Checking } \\
\text { - Selling }\end{array}$ \\
\hline Wiener Dog & Hierarchy & $\begin{array}{l}\text { - Stability and Control } \\
\text { - Internal Focus and } \\
\text { Integration }\end{array}$ & $\begin{array}{l}\text { - } \text { Conformity } \\
\text { - Division of Labor } \\
\text { - Efficiency } \\
\text { - Standardization }\end{array}$ & $\begin{array}{l}\text { Behavioral Conforming } \\
\text { - Less mindful } \\
\text { - Routinized } \\
\text { - Automatic }\end{array}$ & $\begin{array}{l}\text { - Documenting } \\
\text { - Repeating }\end{array}$ \\
\hline
\end{tabular}




\subsection{Clan Culture: Classic Pizza}

Classic Pizza is an average pizza parlor style restaurant with 25 fulltime and part time employees. They are a locally based chain with 14 restaurants scattered throughout New England, but operate and provide an impression of a local family owned restaurant. The restaurant originally opened in the 1930s and the pizza menu was added in 1950s. The restaurant serves other items, however, pizza is the main focus of the menu, which does not change very often. Classic Pizza is open all day and has a menu for every meal. Their clients range from typical college students to town residents who have been coming to Classic Pizza for years. Their staff consists largely of older employees in their 50s and 60s, but also includes some college-aged workers. The staff is mostly family based; some staff members are part of the founding family. Our interviews suggested that the staff and the restaurant viewed itself as a close-knit family, where the well-being of its staff appeared a primary concern while responding to customer needs, a secondary one. One waiter explained: "The staff is very important. Everyone goes out of their way to help each other - we are a team here, even outside work. Just this week, Steve picked up Mary for a shift because her car was broken." While the pizza is famous in the area, consistent with their tradition with little emphasis on change, the pizza and menu has remained the same for years. Another waiter commented: "The only thing that changes are the prices, and all customers know the menu by heart." Based on our interviews and analysis, we identified this restaurant as a clan-based culture. Our fieldwork suggested that the core values underpinning this clan-based culture could best be described as emotional in nature driving two important rituals: storytelling and relationship building.

Emotional Rituals: Storytelling: During our interviews, we quickly noted the importance of social interaction among employees. In order to fit in with the crowd, everyone seemed to understand the expectation of "family" and to value creating and maintaining emotional bonds 
through sharing much information about each other's' private life. When probing on this pattern, participants explained that sharing and opening up about personal challenges, and everyday personal drama, solidified a sense of camaraderie. As such, these stories were generally not linked with events from the restaurant, but rather personal challenges, news and general daily life stories that operated to further bond members of the organization. Moreover, because many of the staff were considered friends outside work, professional and private relationships were often blurred, which meant that stories at work could involve stories in the form of gossip and events involving other staff members. The ritual of storytelling could occur at any point, but became more prominent during early and late shifts when employees worked on team tasks (e.g., moving tables, cleaning, etc.). Underlying storytelling as a ritual was an assumption of belonging to some something greater than oneself - an emotional connection to a family. As one waitress explained: "Working shoulder to shoulder, I quickly understood that we talk about our lives with the others, we build strong ties and we are very loyal to each other." Another waiter commented on the importance to conform: "We have had some people here [employees] that weren't so comfortable chatting with others about themselves, it tends to be a little awkward when they stick to themselves. They tend to leave and go and work at a different place." Storytelling played a key role in terms of preserving the core value of family, and at times, it seemed that this ritual was part of why employees returned to the restaurant.

Emotional Rituals: Relationship Building: A related ritual linked with family values was the emphasis on relationships, which was forged at work but also extended to interactions outside work. Staff and managers engaged in social activities such as going to a regular "movie night" as a group and spending time together on off-days. When probing on these patterns as to why this was important, the consistent response was "friendship." That is, the relationship building at Classic Pizza existed at a deeper level, where everyone was considered family, and that going 
above and beyond for a colleague was a clear expectation. When probing on how staff learnt the ritual of relationship building at work, one waiter explained the importance of helping out if colleagues struggled and could trust others for help: "We learn quickly that we help one another. If you are sick and you want someone to cover for you, it happens. If someone struggles to successfully wait on all of their tables, another waitress quickly helps out. We may go so far as to put in orders for the other waitress. We call this "putting in the tab." We [the waiting staff] are always asking each other if they are doing okay and if they need any help. We do anything we can for one another to ensure that the business runs like a well-oiled machine." Helping your colleagues at work with non-work related issues further demonstrated the importance of helping out as another waitress explained: “The other day, Jenny's car didn't work, so I came over and picked her up for work. That's not a big deal, we all help each other. Last month, Sue helped me with picking up my kid so I could finish my shift.” Newcomers also quickly became exposed to the importance of relationships, explained by a waiter: "When one waiter started at the restaurant, he had to call out sick almost immediately. Instead of the staff being annoyed and "writing up" the new guy, we welcomed the waiter back with open arms; this is important to us." Another recently hired waitress commented: "You find out very fast that you are an important person for the family here, it's like my relationship with the others is more important than to sell pizza here."

Based on our fieldwork, core values of family were institutionalized through two rituals involving storytelling and relationship building, which we formally state in our first proposition:

Proposition 1: In clan cultures, core values of family are institutionalized through emotional rituals of storytelling and relationship building.

\subsection{Ad Hoc Culture: Eclectic Table}


Eclectic Table is an independent small restaurant run by two co-owners, one of which manages the restaurant on a daily basis. The restaurant has a high price point menu with a casual feel that focuses on farm fresh food. The staff of 12 is primarily made up of people who want to make this job a career around exciting and novel dishes. There is very little emphasis on hierarchy at the restaurant and everyone is considered to be on an equal playing field. The environment is casual with limited seating. The ambiance is rustic with clear-coated red brick walls and smooth jazz playing in the background. The restaurant features both a formal dining area as well as a bar area. Their customers are generally established professionals and senior people with a menu that includes high quality items that are priced in line with the clientele. While the menu generally changes at least four times a year to match seasonal dishes, the restaurant prides itself on meeting customer preferences and frequently customizes a dish. Our fieldwork suggested deeply rooted core values of change, creativity and responsiveness to customer demands that manifested themselves through cognitive rituals involving collaborating and problem-solving. Based on our interviews and analysis, we identified this restaurant as an ad hoc-type culture.

Cognitive Ritual: Collaborating: During our fieldwork, our participants were quick to point out the importance of making perfectly executed novel dishes in a collaborative setting. Probing on this further, one cook stated that: "we always try to express our ideas - it is always good to exchange opinions and experience." As a learning ritual, collaborating occurred in formal brainstorming team sessions where individual ideas and new dishes were presented, critiqued, and modified based on feedback from the rest of the staff in the meeting. The managing owner explained that sharing ideas is part of an expectation: "If you don't want to grow and expand your knowledge about food and share your ideas, this is not the place for you. In our team meetings, we typically cook with unique ingredients and we try different wines with different dishes." One 
waiter commented "When I first started here, it was really cool to see how this place worked; they asked me for my opinion, and I was first a bit uncomfortable, but I got used to giving my two cents." These sessions also served as basis of keeping a menu interesting and evolving (apart from small core dishes frequently requested by customers) to retain and attract new customers. Interestingly, the value of creativity operating through the ritual of collaborating also taught and reinforced a non-hierarchical workplace, whereby all members could contribute. Similarly, Stierand et al. (2014) noted the relationship between culture and creativity in top restaurants. One cook explained: "We are all part of making the menu, and we are all constantly learning about new dishes." Another waiter explained: "I love the fact that I am part of creating dishes - it's not a cook's role, we are all here because we love new food. It's fun to experiment at home and then come to work and share your dish and see how we can make it even better as a team.”

Cognitive Ritual: Problem-Solving: In addition to the emphasis on collaborative menu creation, a second ritual that emerged in our fieldwork was empowered problem-solving. Waiters and bartenders were encouraged to find different alternatives to address customers with different taste preferences, dietary restrictions, allergies or other food-related questions. Problem-solving was also closely linked with the ritual of collaboration, which was explained by one cook: "Our team meetings where we try different things and learn what goes well together, also means that the waiter can respond better to customers and quickly come up with alternative suggestions, which will improve the dining experience." Along the same lines, a waiter commented that: "We really get to try a lot of things to broaden our minds here. They [co-owners] also encourage us; actually, it is expected of us to develop our own expertise in areas that we find interesting. This helps when we have customers that have special dietary restrictions, because we know what food items can work well together and we can modify the dish." In sum, collaborating and problemsolving rituals occurred based on formal expectations from all members of the restaurant, 
including the two co-owners, cooks, waiters and bartenders. Moreover, it was further driven by each person's genuine core values in food and exploring creative new ways to combine different ingredients and change existing recipes. Hence, our second proposition formally states:

Proposition 2: In an ad hoc culture, the core values "change" and "creativity" are institutionalized through cognitive rituals, namely collaborating and problem-solving.

\subsection{Market Culture: Taco City}

Taco City is a restaurant that focuses on Mexican cuisine. It is a small chain restaurant that features several branches across the northeast. The first restaurant opened for business in the 1980s and includes locations spread across New England. The restaurant serves dinner only. The staff includes 30 employees, mostly made up of college students, and is managed by four managers. The restaurant enjoys a broad customer base, ranging from college students to professionals. Core values that quickly emerged in our fieldwork were performance and competition. These values were present and noted in a variety of ways, including new employee training, being held accountable for meeting sales quotas, and made explicit when individual sales numbers were made public and compared. The restaurant took pride in its customer service built around values of performance, which drove two rituals: number checking and executing. Based on our interviews and analysis, Taco City was identified as a market culture.

Behavioral Performance Rituals: Number Checking: Our fieldwork and analysis suggest that Taco City's core values were driven by rituals of behavioral conformity, and we labeled the first ritual as number checking. Employees were clearly expected to follow routines in order to maximize sales numbers each night. During our interviews with one manager, he explained how each waiter's weekly overall sales were tracked, compared and posted symbolically on the wall by the managers' office. One waiter explained that "Checking your numbers is like a thing here; we make a big deal about it". Number checking as a ritual was further enacted through ongoing 
sales contests among the waiters themselves regarding who could sell the most mixed drinks, specials, desserts, etc. One manager explained: "The more they sell, the more they can get themselves." Weekly overall restaurant sales, and where the restaurant ranked among other restaurants in the chain, were posted as well. Another waitress commented: "We get sales goals for the night, and we also have competition for selling gift cards and if you win, your name goes into a drawing to win prizes." A third waiter commented on the value of results: "It's all about the numbers here. You learn that quickly. You can work somewhere else and have fun, but here, it's competitive, and you quickly pick up on it by working here".

Behavioral Performance Rituals: Selling: Conformity to values of performance was perhaps even more evident in a second ritual we labeled selling. Behavioral conformity within the context of selling was explained by one manager describing the hiring and training process: "Each newcomer has to go through a rigorous week-long training program, including job shadowing the first three days with a practical exam where the trainee waiter serves the manager." He further explained that this week-long training culminates with a written pass/fail exam. Routines are designed to teach and reinforce the art (i.e., core value) of executing a sales script to please the customer, which would translate into a larger final check. One waitress explained: "I was drilled on the 'two second rule' for a long time. This is where the customer will decide if they like you or not within their first two seconds of meeting you. If they like you, you sell more. For every table, I have to perform the same script and add whatever special sales item we are pushing that night." This selling ritual was not only intended to inform customers about dinner specials, more importantly, it was symbolically repeated to further remind the waiter about the importance of selling. Each employee was given a ten-page employee manual, which could also be found on the counter in the staff room. It operated as a symbol for consistent execution of the scripted sales routine. The implication for not following script was clear. As another waiter explained: "The 
packet explains everything about the job. It even gets into basic abilities like laying a menu on the table in front of the customer. The packet also goes through the dress code and provides 'reasons for dismissal' from the restaurant." Another waiter commented "We have to follow the rules; if we don't, we will get told very quickly to change and refer to the manual." The market culture, viewed through these rituals, operated on the assumption of employee performance through number checking and executing sales scripts. Interestingly, these employee-focused rituals of competition among the staff served to strengthen the culture rooted in performance; they drove belonging and a desire to win in a friendly game of sales competition. Hence, our third proposition formally states:

Proposition 3: In a market culture, the core value "performance" is institutionalized through behavioral performance rituals, namely number checking and selling.

\subsection{Hierarchy Culture: Wiener Dog}

Wiener Dog is a standalone restaurant focusing on a wide range of hot dogs as its niche but features other food items as well. The restaurant has a "sports bar" feel to it with a bar with at least ten beers on tap, a few video game machines in one corner, and several large-screen televisions mounted on walls. The restaurant opened for business in 2012 and serves breakfast, lunch and dinner at a low price point. There are a total of 15 full time and part time employees and most of the staff are local college students. The staff is overseen by the owner, who manages the restaurant on a daily basis and lives literally a block away from the restaurant. The restaurant caters to a broad customer base with generally high volume of customers during lunch time. The menu, including over 20 elaborate types of hotdogs, does not change, except for limited weekly specials. The underlying core value at Weiner Dog in contrast to the other restaurants in the study was the emphasis on behavioral conformity. Through our fieldwork, core values at Wiener Dog quickly emerged as efficiency through high division of labor, close managerial supervision, 
formal rules and policies, with less concern for customer preference or menu change. Based on our interviews and analysis, we identified Wiener Dog as a hierarchy-based culture, where core values of conformity and efficiency were institutionalized through behavioral rituals we labeled as documenting and repeating.

Behavioral Conforming Rituals: Documenting: Our first ritual, documenting, emerged in our field work and analysis and was symbolically performed through written communication. While all restaurants in our study used some type of communication to take orders, at Wiener Dog, documentation and formal written communication was much more pronounced and used to reduce variance from standards - it clearly was a core value. The behavior of documenting was symbolic in a sense that it displayed the value of efficiency and conformity. When probing on this pattern, the owner stated that this system was believed to enhance efficiency: "We have designed this system over time and we think it's optimal to handle a large crowd, and we are not improvising here." Learning the importance of documenting as a behavioral ritual occurred through a large white dry-erase board mounted on the wall in the back of the restaurant out of customers' view. Anytime an employee noticed something missing, the expected behavior was to add it to the whiteboard in order to document a missing item that needed either to be prepared or purchased for the next day's operation. One waiter explained, "The white-board is key for us, I quickly learned that nothing occurs unless it's on the board. If it's not on the board, it's not happening." Another waiter explained: "When I first started here, I remember I told the prepping guy, hey we need more diced onions. He replied, is it on the board? I said, nope. He goes, well, then how do I know I need to dice?"

The ritual of documenting was also evident through their "ticket system" that guided the ordering process. Once an order had been placed by the cash register, the ticket was hung on a string between the cash register and the cooking stations, visible to both staff and customers. 
Both the white dry-erase board and the ticket system operated to guide and reinforce the employee action of documenting. One chef explained: "The first thing I do when I get in is to look at current tickets to see if anything needs to be cooked or prepared. If there are no tickets, I look at the prep board [white dry-erase board] to see if there are any onions or tomatoes that need to be cut."

Behavioral Conforming Rituals: Repeating: The core value of conformity and efficiency was also symbolized in a second ritual that we refer to as repeating - a behavioral ritual based on product conformity and customer interactions. This ritual could manifest itself through product consistency. For example, one cook stated that: "You cannot give one person more fries than normal. Doing this, even once, will change that person's expectations for future visits." The ritual of product consistency was further reinforced through written recipes stipulating the exact toppings on a particular dog. This ritual extended to educating customers about product consistency. During our field observation, we experienced this firsthand as a customer ahead of us placed an order. The restaurant owner, who frequently operated the cash register, regularly engaged in conversations with customers as to what toppings really belonged on different types of hot dogs. The interaction we observed between the owner and a customer made this point explicit. After the customer asked for a modified version of a "Chicago Dog," the owner told the customer: “A Chicago Dog is a classic man, don't mess with a perfect dog, you can't order it without white onions and yellow mustard!" The ritual of repeating was also evident in the conformity of symbolic language among the staff. The restaurant owner explained: "To interact with customers, we have a [scripted] procedure to explain to the customer what the menu is. The right terminology is very important to us. This is to eliminate confusion, both for the staff and for the customer. If we get an order wrong, we lose money." As such, the core value of efficiency at 
Weiner Dog appeared through rituals of documenting and repeating. Our final proposition formally states:

Proposition 4: In a hierarchical culture, the core value "efficiency" is institutionalized through the behavioral efficiency rituals of documenting and repeating.

\section{Discussion}

This study responds to the call for more research on workplace rituals (Smith and Stewart, 2011) and attempts to examine workplace rituals as institutional learning mechanisms for the transmission of core values in restaurants. It draws on Cameron and Quinn's (1999) four types of organizational cultures to identify eight variations of emotional, cognitive, and behavioral rituals focused on employees that contribute to learning about and strengthening existing organizational cultures. We outline our theoretical contributions next.

\subsection{Theoretical Contributions}

Framing rituals as a way to transfer core values to new hires sheds light on the conflict between owners and new/existing members to forge and maintain a distinct organizational culture. We operationalized rituals as an institutionalized process that embeds core values that impose conformity on individuals in order to maintain the status quo rather than engage in a change process, or as Durkheim (1961) would call it - sustaining social order. While studies of rituals in the restaurant context is limited, some evidence suggests that rituals are used as a tool to strengthen commitment through acknowledging employees' hard work (Fine, 2009; Woods, 1989). Others have examined rituals from a consumer consumption and pop culture perspective (e.g., Kottak, 1978; Osman et al., 2014; Visser, 2015). Rituals, such as when employees sing happy birthday (Otnes and Lowrey, 2004) to a customer (where the performance's "audience" is the entire restaurant), have also been described as a marketing tool (Gardner and Wood, 1991). Missing in this debate is the focus on employees themselves, which we add insights into. Our 
ritual lens takes a deeper look at how social activities (e.g., work practices, routines or events) linked with core values, are enacted by themselves for themselves. This is a very different use of rituals, moving the focus away from customers as the primary audience of the employee's performance, to a value-driven symbolic phenomenon centered on the employee's actions. Specifically, employee-focused rituals as a learning mechanism applied at two levels. First, individuals learnt how to perform (action) the ritual itself. Second, while performing the ritual, individuals also learnt to recognize the underlying value as to why they were performing the ritual. Both types of learning reinforce and strengthen the restaurant's culture. As rituals are repeated, members' understood what it means 'to do the right thing'. Culture is materialized through participation. Employees that either fail to embrace core values or fail to engage in rituals are likely to leave the organization, such functional turnover further strengthens the organization.

More broadly, this study adds to research on organizational culture, specifically involving industry patterns of macro cultures in restaurants (Wood, 2010). There is some evidence suggesting similarities with other industries based on shared values (Mulvaney, et al., 2007; O’Neill, 2012; Woods, 1989). O’Neill (2012) offered findings regarding patterns of a "party culture" in hotels where factors such as hotel brands, location classification, and hotel size - not to mention the nature of the organizational culture and age of employees - impact whether a party culture is likely to exist. We do not dispute cultural patterns in a particular industry, our findings indicate that restaurants, even within similar market segments, can have very distinct cultures. Our study suggests that employee-focused workplace rituals can alleviate some of the potential negative consequences of a party culture, where existing value-based standard operating procedures could be compromised when professional and personal lines blur. 
There is also evidence suggesting that restaurant managers (and owners) can share similar values. Woods (1989) and Fine (2009) found common values among successful restaurant managers such as: hard work, hyperactive, goal oriented, hands-on, and fun loving. These values may characterize many managers, but they are not unique to restaurants and can be shared within and across different industries such as retail, travel, and financial services. We did note value similarities among restaurant owners such as "hard work" and "goal oriented". Yet, hard work and goal orientation would seem to operate as necessary principles but insufficient for developing a competitive edge. These broader, perhaps generic, values are likely to be exhibited in workplace rituals that can be found in any company and which are rooted in macro cultures. That is, most restaurants would share similar rituals, such as "greeting customers" and "after work drinks". However, given our research questions, our objective was to examine differences across cultures and offer more complexity and granularity among restaurant cultures. Clearly, additional research is needed and we encourage scholars to examine core values and rituals across various segments within hospitality and foodservice activities.

\subsection{Practical Implications}

Our findings raise several practical implications. We view learning of core values as an important outcome of rituals, which may add to a competitive edge. Incorporating core values guides the daily work of staff members and can translate into higher quality products and service. This logic has received wide support (e.g., Barney, 1991). In the human resource management literature (HRM), the general argument is that employees who are managed by a set of HRM practices can create a competitive advantage (Lashley, 2012). We add to this line of research, and further unpack this "black box" as we illustrate the importance of workplace rituals. Practically, rituals serve to alleviate the transition phase related with staff turnover, which is a recurring challenge in the restaurant industry. In a sense, rituals operate as learning tool to guide and 
socialize newcomers to fit with the organization's values. Rituals also operate as a reinforcing learning mechanism to guide new and existing employee behavior, which reduces the need for hands-on management, and can free up owners' time for more strategic work. Moreover, rituals can serve as both a recruiting and retention tool, saving time and energy in finding replacement staff. For example, outlining workplace rituals during initial interviews will quickly signal a potential person-organization fit (O'Reilly et al., 1991) and help retain those that buy into the shared values system.

There are also potential negative consequences of using workplace rituals for a value-driven organization. While rituals can boost employee cohesion, they must be carefully designed for the right staff in mind. We noted in our fieldwork that some individuals felt pressured to engage in rituals rather than seeing them as positive, spontaneous and voluntary, which resulted in turnover. Collins (2014) argued that when rituals feel imposed, they tend to provoke resentment and disgust, and can even become toxic. Thus, the challenge for restaurant owners and managers is to carefully use and be vigilant about rituals that may have either outlived their usefulness or created unintended consequences, while still attempting to maintain core values.

A second challenge involves congruency. In order for a culture to have real impact and potentially generate positive organizational outcomes (Barney, 1986), for example through superior product as in the case of Eclectic Table, or through speed of service as in the case of Wiener Dog, the strength of the culture is contingent upon the symbolic nature of existing rituals and their congruency with the espoused core values (Denison, 1984, Saffold, 1988; Sorensen, 2002). Congruency can be further supported to the extent an organization fosters and supports a set of workplace rituals that are geared towards the same underlying core values. However, rituals that are incongruent would likely have the opposite effect (even toxic). For example, one informant at Wiener Dog stated that he improvised at times in his work, which would seem to run 
counter to its core value of standardization and perhaps weaken the culture over time. Thus, restaurant managers need to identify and foster rituals consistent with their core values and discard those that do not foster strong culture.

\subsection{Limitations and Future Research}

There are several limitations with this study that call for additional research. First, our study is limited to four restaurants, with a specific focus on owners' core values. However, culture is a complex phenomenon, which can include a range of values (e.g., broad industry values) with corresponding workplace rituals. Various values can exist within the same organization creating sub-cultures where different workplace rituals are performed in different functions (i.e., rituals linked with roles including cooks, bartenders, servers etc.) or hierarchical levels within the organizational structure (Cooke and Rousseau, 1988), which the study did not address. Second, it should be noted that, although we framed each restaurant according to one dominant cultural type, each restaurant showed some evidence of all types of rituals (i.e., emotional, cognitive and behavioral). It seems likely that some rituals would serve as primary and others more secondary rituals or what Smith and Stewart (2011) would call full rituals versus ritual-like activities. Tension between primary and secondary rituals and the values they instill is likely to arise within the organization and its respective sub-cultures. We did not address these ritual overlaps which offer an important future research avenue for examining cultures that would appear hybrid or schizophrenic in nature.

Finally, additional comparative research is needed as well. Our study did not shed much light on whether certain cultural types along with their supportive rituals are more likely to produce stronger cultures; whether a clan-based culture is more likely to have a stronger culture than a hierarchy culture. While there are a range of factors that would impact this relationship, it would seem plausible that emotional rituals, for example those found at Classic Pizza, would produce a 
stronger culture in contrast to behavioral rituals that are more transactional in nature as identified at Wiener Dog and Taco City. The fact that employees at Classic Pizza also enjoyed longer tenure would lend support for this argument. Our study shed important light on the link between culture and rituals, however, the limitations outlined above demonstrate the need for additional work to be done in the general management research domain and specifically within the context of hospitality and restaurants. 


\section{References}

Abrahamson, E. \& Fombrun, C.J. (1994). Macrocultures: Determinants and consequences. Academy of Management Review, 19(4), 728-55.

Adler, P. S., Kwom, S., \& Heckscher, C. (2008). Professional work: The emergence of collaborative community. Organization Science, 19(2), 359-376.

Argyris, C., \& Schön. D.A. (1996). Organizational learning II: Theory, method, and practice. London: Addison-Wesley.

Barney, J.B. (1986). Organizational culture: can it be a source of sustained competitive advantage? Academy of Management Review, 11(3), 656-665.

Barney, J.B. (1991). Firm resources and sustained competitive advantage. Journal of Management, 17(1), 99-120

Bell, C.M., \& Aslan, R. (1997). Ritual: Perspectives and dimensions. New York: Oxford University Press.

Cameron, K.S., \& Quinn, R.E. (1999). Diagnosing and changing organizational culture: Based on the competing values framework. New Jersey: John Wiley \& Sons.

Clark, M.A., \& Wood, R.C. (1998). Consumer loyalty in the restaurant industry-a preliminary exploration of the issues. International Journal of Contemporary Hospitality Management, 10(4), 139-144.

Coffey, V. (2010). Understanding organisational culture in the construction industry. New York: Routledge.

Collins, R. (2014). Interaction ritual chains. New Jersey: Princeton university press.

Cooke, R.A., \& Rousseau, D.M. (1988). Behavioral norms and expectations a quantitative approach to the assessment of organizational culture. Group \& Organization Management, 13(3), 245-273

Crossan, M.M., Lane, H.W., \& White, R.E. (1999). An organizational learning framework: From intuition to institution. Academy of Management Review, 24(3), 522-537.

Cumberland, D., \& Herd, A. (2011). Organizational culture: Validating a five windows qualitative cultural assessment tool with a small franchise restaurant case study. Organization Development Journal, 29(4), 9.

Davidson, M.C. (2003). Does organizational climate add to service quality in hotels? International Journal of Contemporary Hospitality Management, 15(4), 206-213.

Dawson, M., Abbott, J., \& Shoemaker, S. (2011). The Hospitality Culture Scale: A measure organizational culture and personal attributes. International Journal of Hospitality Management, 30(2), 290-300. 
Deal, T.E., \& Kennedy, A.A. (1982). Corporate cultures: The rites and rituals of corporate life. Reading, MA: Addison-Wesley.

Denison, D.R. (1984). Bringing corporate culture to the bottom line. Organizational Dynamics, 13(2), 5-22.

Durand, R., Rao, H., \& Monin, P. (2007). Code and conduct in French cuisine: Impact of code changes on external evaluations. Strategic Management Journal, 28(5), 455-472.

Durkheim, E. (1961). The elementary forms of the religious life. New York: Collier Books.

Fine, G.A. (2009). Kitchens: The culture of restaurant work, updated with a new preface. Berkeley, CA: University of California Press.

Gardner, K., \& Wood, R.C. (1991). Theatricality in food service work. International Journal of Hospitality Management, 10(3), 267-278.

Hamilton, D. (1994). Traditions, preferences, and postures in applied qualitative research. In N.K. Denzin \& Y.S. Lincoln (Eds.), Handbook of qualitative research (pp. 60-69). Thousand Oaks, CA: Sage.

Hammersley, M. (2010). Reproducing or constructing? Some questions about transcription in social research. Qualitative research, 10(5), 553-569.

Islam, G., \& Zyphur, M.J. (2009). Rituals in organizations a review and expansion of current theory. Group \& Organization Management, 34(1), 114-139.

Kluver, J., Frazier, R. \& Haidt, J. (2014). Behavioral ethics for homo economicus, homo heuristicus, and homo duplex. Organizational Behavior and Human Decision Processes, 123, 150-158.

Kottak, C.P. (1978). Rituals at McDonald's. Journal of American Culture, 1(2), 370-376.

Koutroumanis, D.A., Watson, M.A., \& Dastoor, B.R. (2012). Developing organizational culture in independently owned restaurants: Links to service quality and customers' intentions to return. Journal of Applied Business Research, 28(1), 15-22.

Kyriakidou, O., \& Gore, J. (2005). Learning by example: Benchmarking organizational culture in hospitality, tourism and leisure SMEs. Benchmarking: An International Journal, 12(3), 192-206.

Lashley, C. (2012). Empowerment: HR strategies for service excellence. London: Routledge.

Madera, J.M., Dawson, M., Neal, J.A., \& Busch, K. (2013). Breaking a communication barrier the effect of visual aids in food preparation on job attitudes and performance. Journal of Hospitality \& Tourism Research, 37(2), 262-280.

Mathison, S. (1988). Why triangulate? Educational researcher, 17(2), 13-17. 
Miles, M.B., \& Huberman, A.M. (1994). Qualitative data analysis: An expanded sourcebook. Thousand Oaks, CA: Sage.

Miller, G. (1985). Work, ritual structure and the legitimation of alternative communities. Work and Occupations, 12(1), 3-22.

Mulvaney, R., O’Neill, J., Cleveland, J. \& Crouter, A. (2007). A model of work-family dynamics of hotel managers. Annals of Tourism Research, 34(1), 66-86.

Neal, J. (2013). Creating enlightened organizations: Four gateways to spirit at work. New York, NY: Palgrave Macmillan.

Ogbonna, E. (1993) Managing Organizational Culture: Fantasy or Reality? Human Resource Management Journal, 3(2): 42-54.

O’Neill, J. W. (2012). The determinants of a culture of partying among managers in the hotel industry. International Journal of Contemporary Hospitality Management, 24, 81-96.

Opazo, M.P. (2012). Discourse as driver of innovation in contemporary haute cuisine: The case of elBulli restaurant. International Journal of Gastronomy and Food Science, 1(2), 82-89.

O'Reilly, C.A., Chatman, J., \& Caldwell, D.F. (1991). People and organizational culture: A profile comparison approach to assessing person-organization fit. Academy of Management Journal, 34(3), 487-516.

Osman, H., Johns, N., \& Lugosi, P. (2014). Commercial hospitality in destination experiences: McDonald's and tourists' consumption of space. Tourism Management, 42, 238-247.

Otnes, C.C., \& Lowrey, T.M. (Eds.). (2004). Contemporary consumption rituals: A research anthology. New York: Taylor \& Francis.

Øgaard, T., Larsen, S., \& Marnburg, E. (2005). Organizational culture and performance-evidence from the fast food restaurant industry. Food Service Technology, 5(1), 23-34.

Parsa, H.G., Self, J.T., Njite, D., \& King, T. (2005). Why restaurants fail. Cornell Hotel and Restaurant Administration Quarterly, 46(3), 304-322.

Radcliffe-Brown, A.R. (1952). Structure and function in primitive society: essays and addresses. London: Cohen \& West.

Rao, H., Monin, P., \& Durand, R. (2003). Institutional change in Toque Ville: Nouvelle cuisine as an identity movement in French gastronomy. American Journal of Sociology, 108(4), 795-843.

Saffold, G.S. (1988). Culture traits, strength, and organizational performance: Moving beyond "strong" culture. Academy of Management Review, 13(4), 546-558.

Schein, E.H. (2010). Organizational culture and leadership (2nd Ed.). San Francisco: JosseyBass.

Scott, W.R. (1995). Institutions and organizations. Thousand Oaks, CA: Sage. 
Smart, J.C., \& John, E.P.S. (1996). Organizational culture and effectiveness in higher education: A test of the "culture type" and "strong culture" hypotheses. Educational Evaluation and Policy Analysis, 18(3), 219-241.

Smith, A.C.T., \& Stewart, B. (2011). Organizational rituals: Features, functions and mechanisms. International Journal of Management Reviews, 13, 113-133.

Sorensen, J.B. (2002). The strength of corporate culture and the reliability of firm performance. Administrative Science Quarterly, 47, 70-91.

Sosis, R. \& Alcorta, C.S. (2003). Signaling, solidarity and the sacred: the evolution of religious behavior. Evolutionary Anthropology, 12, 264-274.

Sparrowe, R.T. (1994). Empowerment in the hospitality industry: An exploration of antecedents and outcomes. Journal of Hospitality \& Tourism Research, 17, 51-73.

Stierand, M., Dörfler, V., \& MacBryde, J. (2014). Creativity and innovation in haute cuisine: Towards a systemic model. Creativity and Innovation Management, 23(1), 15-28.

Schwandt, T.A. (2000). Three epistemological stances for qualitative inquiry: Interpretivism, hermeneutics, and social constructionism. In N.K. Denzin \& Y.S. Lincoln (Eds.), Handbook of qualitative research (pp. 189-213). Thousand Oaks, CA: Sage.

Trice, H.M. and Beyer, J.M. (1984). Studying organizational cultures through rites and ceremonials. Academy of Management Review, 9, 653-669.

Turner, V. (1967). The Forest of Symbols. Aspects of Ndembu Ritual. Ithaca, NY: Cornell University Press.

Van Gennep, A. (2011). Rites of passage. Chicago: University of Chicago Press.

Visser, M. (2015). The rituals of dinner: The origins, evolution, eccentricities, and meaning of table manners. New York, NY: Open Road Media.

Wood, R.C. (2010). Strategic questions in food and beverage management. London: Routledge.

Woods, R.H. (1991). Surfacing culture: the 'Northeast Restaurants' case. International Journal of Hospitality Management, 10(4), 339-356.

Woods, R.H. (1989). More alike than different: The culture of the restaurant industry. The Cornell Hotel and Restaurant Administration Quarterly, 30(2), 82-97. 